\title{
Ocorrência de onicomicose em pacientes atendidos em consultórios dermatológicos da cidade do Rio de Janeiro, Brasil ${ }^{*}$ \\ Occurrence of onychomycosis among patients attended in dermatology offices in the city of Rio de Janeiro, Brazil ${ }^{*}$
}

Adauto José Gonçalves de Araújo ${ }^{1}$

Maria Auxiliadora Jeunon Souza
Otilio Machado P. Bastos

Jeferson Carvalhaes de Oliveira ${ }^{4}$

\begin{abstract}
Resumo: FunDAMENTOS - A infecção por dermatófitos afeta aproximadamente $40 \%$ da população mundial, representa $30 \%$ de todas as infecções micóticas cutâneas, e a onicomicose por dermatófito é a mais freqüente, representando entre 18 e $40 \%$ de todas as onico patias. A onicomicose é causada primariamente por dermatófitos, Candida spp. e outros fungos não dermatófitos. Entre os agentes fúngicos, os dermatófitos, particularmente Trichophyton rubrum, são os mais comuns desses patógenos. Atualmente, Candida spp. pode invadir a unha distal e proximal. As onicomicoses provocadas por fungos não dermatófitos vêm aumentando em sua prevalên cia, e, pela similaridade clínica com a onicomicose por dermatófito, é necessário o diagnóstico laboratorial para sua diferenciação. OBjETIVOS - O objetivo do presente trabalho é avaliar a ocorrência de onicomicose na cidade do Rio de Janeiro.

МÉToDOs - Foram avaliados 2.920 pacientes entre janeiro de 1998 e dezembro de 1999, dos quais 1.416 apresentaram anormalidades nas unhas.

RESULTADOS - A confirmação micológica de onicomicose foi possível em 565 dos 2.920 pacientes, e a prevalência estimada pontual na cidade do Rio de Janeiro é $19,34 \%$. Os homens foram responsáveis por 34,16\% das onicomicoses, e as mulheres por $65,84 \%$. A distribuição por agente etiológico dos 224 pacientes com onicomicose que apresentaram cultura positiva foi: dermatófitos $64,7 \%$, Candida spp. 30,1\% e outros não dermatófitos 5,2\%.

ConClusão- A microbiota fúngica é completamente trocada no mundo periodicamente em sua composição quantitativa e qualitativa, sendo afetada por vários fatores ambientais. Assim, o exame periódico da composição desta microbiota vem a ser vantajoso e de importância epidemiológica e terapêutica.
\end{abstract}

Palavras-chave: arthrodermataceae; Candida, epidemiologia; onicomicose; Trichophyton.

\begin{abstract}
Summary: BACKGROUND - Infection by dermatophytes affects $40 \%$ of the world population and represents $30 \%$ of all mycotic cuta neous infections, onychomycosis being the most frequent disease of the nails, counting for 18 to $40 \%$ of all onychopathies. Onychomycosis is caused primarily by dermatophytes, Candida spp. and other non-dermatophyte fungi. Among the etiologic agents the most common are dermatophytes and especially Trichophyton rubrum Nowadays Candida spp. can invade the distal and proximal nails. Onychomycosis due to non-dermatophyte fungi bas been increasing in prevalence and in view of the clinical similari ty with onychomycosis caused by dermatophytes, a laboratorial diagnosis is necessary for its differentiation.

OBJETIES - The objective of the present work is to evaluarte the occurrence of onychomycosisin the city of Rio de Janeiro.

METHODS - Out of 2920 patients attended between January 1998 and December 1999, 1416 presented abnormalities in their nails. RESULT - Mycological confirmation of onychomycosis was performed in 565 patients and the estimated prevalence in the city of Rio de Janeiro is $19.34 \%$. Women were more affected than men, with a ratio of almost 2:1. The distribution according to etiological agent of 224 patients with onychomycosis and who presented positive culture was: dermatophytes 64.7\%; Candida spp. 30.1\%; and non-dermatophytes $5.2 \%$.

CONCLUSION - The fungal flora changes completely periodically in the world in terms of its quantitative and qualitative composition as it is affected by several environmental factors. Consequently, a periodic exam of the composition of the microflora can be interesting and of epidemiological and therapeutic importance.

Key words: arthrodermataceae; Candida; epidemiology; onychomycosis; Trichophyton.
\end{abstract}

Recebido em 10.10.2001. / Received in October, $10^{\text {th }}$ of 2001

Aprovado pelo Conselho Consultivo e aceito para publicação em 25.11.2002. / Approved by the Consultive Council and accepted for publication in November, $25^{\text {th }}$ of 2002.

* Trabalho realizado no Instituto Oswaldo Cruz. / Work done at "Instituto Oswaldo Cruz".

${ }^{l}$ Pesquisador titular do Departamento de Endemias Samuel Pessoa - ENSPE / FIOCRUZ; Doutor em Paleoparasitologia pela FIOCRUZ. / Titular Researcher, Dept. of Endemic Diseases Samuel Pessoa - ENSPE/FIOCRUZ; Ph.D Paleoparasitology from FIOCRUZ.

${ }^{2}$ Professor adjunto da Universidade Federal Fluminense; Doutor em Parasitologia pela FIOCRUZ. / Adjunct Professor, "Universidade Federal Fluminense"; Ph.D. in Parasitology from FIOCRUZ.

${ }^{3}$ Professora da UERJ; Dermatologista; Chefe do setor de Dermatopatologia da Universidade do Estado do Rio de Janeiro. / Professor, UERJ; Dermatologist; Head of the Dermatopathology Dept., "Universidade do Estado do Rio de Janeiro".

${ }^{4}$ Doutor em Biologia Parasitaria pela FIOCRUZ; Professor adjunto da Universidade Federal Fluminense. / Ph.D. in Parasitic Biology, from FIOCRUZ; Adjunct Professor, "Universidade Federal Fluminense". 


\section{INTRODUÇÃO}

A infecção por dermatófitos afeta aproximadamente $40 \%$ da população mundial e representa $30 \%$ de todas as infecções micóticas cutâneas, sendo as mais comuns as que afetam a pele e as mucosas. ${ }^{1,2}$ As onicomicoses são as mais freqüentes das doenças das unhas, representando de 18 a $40 \%$ de todas as onicopatias. A onicomicose do hálux freqüentemente está associada com tinea interdigitale ou tinea pedis plantar. ${ }^{3}$

A prevalência da onicomicose na Inglaterra situa-se entre três e $8 \% .{ }^{4}$ Em alguns países, como a Irlanda, 15 a $20 \%$ das pessoas, entre 40 e 60 anos de idade, sofrem da doença, sendo a prevalência maior nos idosos. 5

A importância da onicomicose reside no aumento de sua prevalência. Nos Estados Unidos da América do Norte, é estimada entre dois e $13 \%,{ }^{3,6}$ e aproximadamente uma entre cinco pessoas de 40 a 60 anos de idade apresenta onicomicose, os indivíduos idosos apresentando essa infecção., ${ }^{3,6,8}$ em percentual que varia de 15 a $20 \%,{ }^{3,6,7}$ podendo atingir até $50 \%$.

É uma infecção que deve ser considerada importante pelo dano que acarreta. A qualidade de vida dos doentes é prejudicada, a auto-estima pode ser reduzida, a capacidade funcional por vezes é afetada de maneira a interferir nas atividades rotineiras. A onicomicose pode agravar outras afecções clínicas, especialmente no indivíduo idoso; tal como as amputações de membros inferiores nos portadores de diabetes mellitus correlacionadas à onicomicose. Os pacientes diabéticos apresentam prevalência mais alta de onicomicose do que os não diabéticos. A prevalência de onicomicose na unha do pé em pessoas diabéticas em Ontário e Massachusetts é estimada em 32,3\% e 34,9\%, respectivamente. ${ }^{3} \mathrm{~A}$ incidência de infecções secundárias por outros microorganimos é mais alta nos pacientes diabéticos com onicomicose do que em diabéticos que não apresentam tal afecção. ${ }^{9}$ A onicomicose crônica, portanto, pode aumentar os custos dos cuidados com a saúde. O intertrigo interdigital mostra forte associação com erisipela ou celulite da perna. ${ }^{10}$ Outras causas que contribuem para o aumento do número de infectados por dermatófitos são: a epidemia da Aids, o uso incrementado de corticosteróides e antibióticos, e a utilização de drogas imunodepressoras em pacientes transplantados. ${ }^{11}$ Outro elemento de fomento das dermatofitoses é o aumento de sua freqüência em academias de condicionamento físico e a maior participação da população das cidades em atividades esportivas comunitárias. ${ }^{12}$

Existem diferenças geográficas na epidemiologia e etiologia das onicomicoses, especialmente na freqüência de cada grupo de fungos responsável pela infecção. T. rubrum é a espécie mais freqüente na Inglaterra, Alemanha, no Canadá, nos EUA e Índia, enquanto a alta prevalência de Candida spp. na unha tem sido relatada na Bélgica, Arábia Saudita e Espanha. Em outras regiões tropicais do mundo, a etiologia da onicomicoses também pode ser atribuída ao Scytalidium spp., fungo filamentoso não dermatófito. ${ }^{6}$

\section{INTRODUCTION}

Infection by dermatophytes affects approximately $40 \%$ of the world population and represents $30 \%$ of all cutaneous mycotic infections, the most common ones being those that affect the skin and the mucous membranes. ${ }^{1,2}$ Onychomycoses are the most frequent of nail diseases, representing 18 to $40 \%$ of all onychopathies. Onychomycosis of the hallux is frequently associated with tinea interdigitalis or tinea plantar. ${ }^{3}$

The prevalence of onychomycosis in England is between 3 and $8 \% .{ }^{4}$ In some countries, such as Ireland, 15 to $20 \%$ of the population in the 40 to 60 years of age bracket suffer from the disease, with greater predominance among the elderly. ${ }^{5}$

The importance of the study of onychomycosis lies in the increase of its prevalence. In the United States of America, it is estimated at between 2\% and 13\%, and approximately one in five people from 40 to 60 years of age present onychomycosis, again the more elderly individuals presenting this infection ${ }^{3,6,8}$ in a percentile that varies from $15 \%$ to $20 \%,{ }^{3,6,7}$ and can reach as much as $50 \%$.

It is an infection that should be considered important because of the damage it causes. The patients' quality of life is impaired, self-esteem may be reduced, and functional capacity at times is affected to such an extent that it interferes in routine activities. Onychomycosis can worsen other clinical afflictions, especially in the elderly individual; as in the case of diabetes mellitus patients requiring amputations of the inferior members because of conditions related to onychomycosis. Diabetic patients present a greater predisposition to onychomycosis than non-diabetics. The prevalence of onychomycosis in the toenails of diabetic individuals in Ontario and Massachusetts is estimated at $32.3 \%$ and $34.9 \%$, respectively. ${ }^{3}$ The incidence of secondary infections of other microorganisms is higher in diabetic patients with onychomycosis than in diabetics that do not present this disease. ${ }^{9}$ Chronic onychomycosis, therefore, can increase the costs of health care. Interdigital intertrigo shows a strong association with erysipela or cellulitis of the leg. ${ }^{10}$ Other reasons that contribute to the increasing number of individuals infected by dermatophytes are: the Aids epidemic; the increased use of corticosteroids and antibiotics; and the use of immunodepressant drugs in organ transplant patients. ${ }^{11}$ Another element in the fomentation of dermatophytoses is the increase of its frequency in academies of physical conditioning and the greater participation of the population of cities in community sporting activities. ${ }^{12}$

There are geographical differences in the epidemiology and etiology of onychomycosis, especially in the frequency found for each group of fungi responsible for the infection. T. rubrum is the most frequent species in England, Germany, Canada, the USA and India, while the high prevalence of Candida spp. in the nail has been reported in Belgium, Saudi Arabia and Spain. In other tropical areas of the world, the etiology of onychomycosis can also be attributed to Scytalidium spp., a nondermatophytic filamentous fungus. ${ }^{6}$ 
Variações entre os relatos podem ser devidas a dis tintos grupos geográficos estudados e respectivas diferenças climáticas, como prováveis determinantes para ocorrência de Scytalidium spp em particular. ${ }^{6}$ Amostragens com variações de outros parâmetros, como idade, hábitos de vida, sexo, localização, tipo clínico, por exemplo, também podem gerar resultados divergentes nos estudos sobre o assunto. Do ponto de vista clínico, considera-se fungo patogênico aquele que, uma vez removido do organismo com terapia antifúngica, permite a cura clínica da unha. ${ }^{13}$

A microbiota fúngica é alterada no mundo periodicamente em sua composição quantitativa e qualitativa, em função de fatores ambientais, como o desenvolvimento urbano, a industrialização, a localização geográfica e condições climáticas, tais como temperatura e tempo de exposição à radiação ultravioleta. ${ }^{4}$ Assim, o exame periódico da composição da microbiota torna-se vantajoso e de importância epidemiológica. ${ }^{1}$ A determinação da etiologia, em alguns casos, deve obedecer a critérios como os existentes para Aspergillus e Scopulariopsis, que só são aceitos como agentes se o exame direto for positivo, além da obtenção de dois isolamentos sucessivos em cultura.

Autores da região de Lodz, Polônia, estudando 2.282 pacientes, isolaram T. rubrum na unha do pé em $8,9 \%$ deles e na unha da mão em $2,7 \%$; T. mentagrophytes var. mentagrophytes na unha do pé em 4,5\%,T. mentagrophytes var. interdigitale na unha do pé em $2,2 \%$. Neste trabalho, os dermatófitos foram isolados da unha do pé em $17,9 \%$ e da unha da mão em $4,3 \% .^{1}$

Os dermatófitos têm sido isolados não só do pó de casa de pacientes residentes, mas também do piso de banheiros públicos e piscinas. ${ }^{14}$

Para prevenir a dermatofitose é importante determinar o período mínimo de penetração do dermatófito no estrato córneo. $\mathrm{O}$ aumento da temperatura e o da umidade são importantes fatores ambientais para o crescimento do fungo. A umidade de $90 \%$ e a temperatura de $35^{\circ} \mathrm{C}$ possibilitam a penetração do fungo em quatro dias. A umidade é mais importante do que a temperatura como fator ambiental de penetração. A umidade interdigital entre o quarto e o quinto dedo do pé é de aproximadamente $98 \% .{ }^{14} \mathrm{Com}$ menos de $90 \%$ de umidade, é possível ao dermatófito penetrar o estrato córneo em poucos dias.

O estudo da freqüência da dermatofitose, na cidade de Porto Alegre em 13 anos, mostrou que é influenciada pela faixa etária, fatores genéticos, condições bioclimáticas, promiscuidade, transpiração, movimento ou migração humana, contato com animais domésticos e contato com chão de piscina e áreas fechadas. ${ }^{15}$

Os fatores que podem contribuir com o aumento de prevalência de onicomicose na população de terceira idade são a redução da taxa de crescimento da lâmina ungueal e o aumento da possibilidade de traumas. ${ }^{16}$

A prevalência de onicomicose em Ontário, Canadá, foi de $11,7 \%$ em homens e $6,5 \%$ em mulheres. A alta pre-
Variations between reports can be due to the distinct groups studied and their respective geographical climatic differences, as probable determinants for the occurrence of Scytalidium spp in particular. ${ }^{6}$ Sampling with variations in other parameters, such as age, life habits, sex, location and clinical type, for instance, can also generate divergent results in studies on the subject. From the clinical point of view, a pathogenic fungus is considered to be that in which its elimination from the organism via antifungal therapy is followed by clinical cure of the nail. ${ }^{13}$

The quantitative and qualitative composition of fungal microbiota undergoes periodic alterations in the world, as a function of environmental factors, such as urban development, industrialization, geographical location and climatic conditions, for example temperature and duration of exposure to ultraviolet radiation. ${ }^{4}$ Such that, a periodic examination of the composition of the microbiota becomes necessary and of epidemic importance. ${ }^{1}$ The determination of etiology, in some cases, should follow criteria such as those for Aspergillus and Scopulariopsis, that are only accepted as agents if the direct exam is positive, despite the obtaining of two successive isolations in culture. ${ }^{1}$

Authors of the area of Lodz (Poland) studying 2,282 patients, isolated: T. rubrum in the toenail of $8.9 \%$ and the fingernail of $2.7 \%$; T. mentagrophytes var. mentagrophytes in the toenail of $4.5 \%$; and T. mentagrophytes var. interdigitale in the toenail of $2.2 \%$. In this work, the dermatophytes were isolated from the toenail in $17.9 \%$ and from the fingernail in $4.3 \%{ }^{1}$

Dermatophytes have been isolated not only in the dust of the patients' residences, but also from the floor of public toilets and swimming pools. ${ }^{14}$

To prevent dermatophytosis it is important to determine the minimum period for penetration of the dermatophyte into the corneum stratum. Increased temperature and humidity are important environmental factors in the growth of the fungus. A humidity of $90 \%$ and a temperature of $35^{\circ} \mathrm{C}$ enable the penetration of the fungus in four days. Humidity is more important than temperature as an environmental factor of penetration. Interdigital humidity between the fourth and the fifth toe is approximately 98\%. ${ }^{14}$ Even with less than 90\% humidity, it is possible for the dermatophyte to penetrate the corneum stratum within a few days.

The study of the frequency of dermatophytosis in the city of Porto Alegre over a period of 13 years, has showed that the development of dermatophytosis is influenced by the age of the patient, genetic factors, bioclimatic conditions, promiscuity, perspiration, demographic movement or migration, care of domestic animals and contact with swimming pool decks and closed areas. ${ }^{15}$

Factors that can contribute to the increased prevalence onychomycosis in the elderly population are reduction in the rate of growth of the ungual covering and a greater possibility of traumas. ${ }^{16}$

The prevalence of onychomycosis in Ontario, Canada is $11.7 \%$ in men and $6.5 \%$ in women. The high 
valência no primeiro grupo em relação ao segundo provavelmente resulta de maior probabilidade de trauma e grande oclusão por uso de calçados. Diferença de taxas de progesterona e esteróides entre os sexos poderia também explicar esse fato, pois essas taxas causam inibição do crescimento dos dermatófitos. ${ }^{16}$

A proporção de pacientes com onicomicose foi maior na unha do pé, ${ }^{4,16} \mathrm{em}$ vários trabalhos, e os fatores responsabilizados por essa diferença foram: o crescimento mais lento e a maior probabilidade de trauma nos pés. A unha do hálux foi mais afetada devido à predisposição de trauma nessa região. A onicomicose da mão é mais diagnosticada do que a infecção do pé por chamar mais a atenção médica, mas certamente é menos freqüente. ${ }^{16}$

Apenas $40 \%$ das unhas com aparência anormal tinham evidência micológica de onicomicose. Muitos dos pacientes com onicomicose relatados por Gupta não tinham ciência de seu diagnóstico. ${ }^{16}$

A onicomicose é doença infecciosa, estando os membros da mesma família sob maior risco de contraí-la de parceiros ou irmãos afetados. ${ }^{3}$ Altos níveis de contaminação em locais de banhos comunitários não podem ser reduzidos, a menos que os indivíduos afetados sejam tratados de forma bem-sucedida. ${ }^{3}$

A onicomicose pode exercer impacto adverso importante na qualidade de vida dos indivíduos afetados, causando redução da auto-estima e possivelmente afetando o potencial de trabalho. ${ }^{1,14}$ As unhas, como componente da extremidade dos dedos, são parte integrante da estrutura sensorial da mão. A perda da margem livre das unhas pode reduzir drasticamente a capacidade sensorial dos dedos, com conseqüente limitação da destreza manual. A onicomicose do pé pode causar dor e desconforto, tornando difícil permanecer em pé, andar e praticar esportes. A infecção pode também resultar em prejuízo significativo para a saúde geral, a aparência física e o desempenho social. A onicomicose pode ter conseqüências psicológicas importantes, incluindo-se constrangimento constante, depressão, ansiedade, preocupação com aparência e receio de situações íntimas. ${ }^{?}$

Ficam objetivadas a ocorrência, etiologia e epidemiologia da onicomicose por dermatófito.

\section{PACIENTES E MÉTODOS}

A amostra populacional foi constituída por doentes atendidos em consultórios dermatológicos da cidade do Rio de Janeiro, Brasil, no período de janeiro de 1998 a dezembro de 1999. Pacientes de todas as idades e com vários problemas dermatológicos eram encaminhados ao laboratório para esclarecimento diagnóstico. As unhas de mãos e pés eram classificadas em normais e anormais, sendo coletado material subungueal para exame micológico apenas das unhas afetadas. A classificação das onicomicoses foi baseada nos quatros tipos clínicos específicos de alterações presentes, segundo Roberts: ${ }^{17}$ prevalence in the first group in relation to the second probably was the result of a greater probability of trauma and greater occlusion in the type of shoes used. The different levels of progesterone and steroids between sexes could also explain this fact because these levels can inhibit the growth of dermatophytes. ${ }^{16}$

The proportion of patients with onychomycosis was higher in the case of toenails, ${ }^{416}$ in several studies, and the factors considered responsible for this difference were: the slower growth and greater probability of trauma in the feet. The nail of the hallux was most affected, due to the likelihood of trauma in this location. Onychomycosis of the hand is diagnosed more often than infections of the foot even though it is certainly less frequent, because it attracts more medical attention. ${ }^{16}$

Only $40 \%$ of the nails with abnormal appearance presented mycological evidence of onychomycosis. Many of the patients with onychomycosis reported by Gupta were not aware of the condition diagnosed. ${ }^{16}$

Onychomycosis is an infectious disease, rendering other members of a family under greater risk of contagion from affected partners or siblings. ${ }^{3}$ High levels of contamination in places such as communal showers cannot be reduced unless affected individuals are treated in an efficient and successful manner. ${ }^{3}$

Onychomycosis can cause an important adverse impact on the quality of the affected individual's life, leading to reduced self-esteem and possibly affecting work potential. ${ }^{1,14}$ The nails, as components of the extremities of the fingers, are integral parts of the sensorial structure of the hand. Loss of the outer edge of the nails can reduce the sensorial capacity of the fingers drastically, with consequent limitation of manual dexterity. While onychomycosis of the foot can cause pain and discomfort, making it difficult to practice sports, walk or even remain standing. The infection can also result in significant damage to general health, physical appearance and social performance. Onychomycosis can have important psychological consequences, including constant embarrassment, depression, anxiety, concern over appearance and fear of intimate situations. ${ }^{7}$

The objective of this work was to focus on the occurrence, etiology and epidemiology of onychomycosis caused by dermatophytes.

\section{PATIENTS AND METHODS}

The population sample constituted patients attended at dermatology clinics in the city of Rio de Janeiro, Brazil, from January 1998 to December 1999. Patients of all ages and with various dermatological problems were referred to the laboratory for diagnostic clarification. The nails of hands and feet were classified as normal or abnormal. Only subungual material from affected nails was collected for mycological exam. Classification of the onychomycoses was based on the four specific clinical types of alteration presented, according to the method of Roberts: ${ }^{17}$

1. Distal and lateral subungual onychomycosis is the 
1. Onicomicose subungueal distal e lateral é o tipo mais comum de onicomicose. Os dermatófitos predominam nesse tipo clínico, com envolvimento ocasional por não dermatófito.

2. Onicomicose superficial branca é uma infecção superficial da unha causada primariamente por T. mentagrophytes e, algumas vezes, pelo mofo Acremonium sp. Esse tipo tem recebido, recentemente, maior atenção por causa da maior ocorrência em paciente com Aids.

3. Infecção subungueal proximal, freqüentemente afetando as unhas dos dedos das mãos, é primariamente resultado de infecção por Candida. No paciente portador de Aids, pode ser causada por dermatófito.

4. Onicomicose distrófica total, caracterizada pela total destruição da placa (lâmina) ungueal, é freqüentemente resultado de infecção dermatofítica.

A amostra clínica da unha foi submetida ao exame micológico direto, após clarificação com $\mathrm{NaOH}$ a $20 \%$, e a cultura em meio de Sabouraud e Mycosel.

A confirmação da dermatofitose foi baseada no crescimento do agente etiológico no meio de cultura. No caso da espécie Candida, o diagnóstico era baseado no exame direto pela presença de hifas, pseudo-hifas e blastoconídios. Quando era isolado fungo não dermatófito, além da hifa no exame direto e do crescimento em cultura, uma segunda coleta era realizada para confirmação do exame micológico.

A pesquisa estatística foi executada por meio de uma amostra de 2.920 pacientes dos consultórios de dermatologia da cidade do Rio de Janeiro; após tabulação foram feitos os cálculos para verificação de prevalência, distribuição, regressão, intervalo de confiança e teste de hipóteses (Tabela 1).

\section{RESULTADOS}

Do total de 2.920 pacientes examinados, 1.107 eram homens e 1.813 mulheres, com média de 39,05 anos. Além dos pacientes com idade ignorada, um foi excluído por não haver a referência da localização da lesão e idade. Pacientes portadores de tinea pedis foram incluídos na pesquisa. Dos 2.920 pacientes, $1.416(48,49 \%)$ apresentavam unhas com aspecto anormal, sendo 358 homens e 1.058 mulheres, média de 46,14 $\pm 0,39$ (erro médio quadrático) anos (Tabela 1).

Do total de pacientes (2.920), a onicomicose esteve presente em 19,35\%. Dos 1.416 pacientes em que se realizou a coleta para exame micológico, houve confirmação micológica de onicomicose em 565 (39,90\%), dos quais 193 eram homens e 372 mulheres, com idade média de 44,88 — 0,69 (erro médio quadrático). Desses, a cultura só foi positiva em $224(7,50 \%$ do total de pacientes, $15,82 \%$ com anormalidade ungueal e $39,65 \%$ com exame direto positivo). Desses 224 pacientes, a unha do pé estava comprometida em 153, assim distribuídos: dermatófito $64,7 \%$, Candida spp 30,1\% e não dermatófito 5,2\% (Tabela 2). O exame direto negativo e a cultura positiva para Candida most common type of onychomycosis. Dermatophytes predominate in this clinical type with occasional involvement of nondermatophytes.

2. White superficial onychomycosis is a superficial infection of the nail caused primarily by $\mathrm{T}$. mentagrophytes and, sometimes, by the mold Acremonium sp. This type has recently been receiving more attention in view of its greater occurrence in patients with Aids.

3. Proximal subungual infection, frequently affecting the fingernails, it results primarily from an infection by Candida. In patients with Aids, it can be caused by a dermatophyte.

4. Total dystrophic onychomycosis, characterized by the total destruction of the nail plate (covering), is frequently the result of a dermatophytic infection.

A clinical sample of the nail was submitted to direct mycological exam, after clarification with $20 \% \mathrm{NaOH}$ and culture in Sabouraud's agar and Mycosel medium.

Confirmation of dermatophytosis was based on the etiological agent's growth in the culture medium. In the case of Candida, diagnosis was based on direct exam for the presence of hyphas, pseudo-hyphas and blastoconidia. When a nondermatophytic fungus was isolated in addition to the hypha in the direct exam and growth in culture, a second sample was collected for confirmation of the mycological exam.

Statistical analysis was performed in the sample population of 2,920 patients attended at dermatology clinics in the city of Rio de Janeiro. After tabulation, calculations were made for verification of prevalence, distribution, regression, confidence limits and test of hypotheses (Table1).

\section{RESULTS}

Of the total of 2,920 examined patients, 1,107 were men and 1,813 were women. The mean age was 39.05 years. Besides the patients of unknown age, another was excluded because there was no reference to either the location of the lesion or age. Patients with tinea pedis were included in the research. Of the 2,920 patients, 1,416 (48.49\%) presented nails with abnormal aspects, of these 358 were men and 1,058 were women; the mean age was $46.14 \pm 0.39$ (least mean square error) (Table 1).

Out of the total patients $(2,920)$ Onychomycosis was present in 19.35\%. Mycological exam was performed in 1,416 patients and there was mycological confirmation of onychomycosis in 565 (39.90\%), of which 193 were men and 372 were women, with a mean age of $44.88 \pm 0.69$ (least mean square error). Of these, the culture was only positive in 224 (7.50\% of the total patients, 15.82\% with ungual abnormality and $39.65 \%$ with positive direct exam). Furthermore, of these 224 patients, there was were involvement of the toenails in 153, distributed as follows: dermatophytic, 64.7\%; Candida spp, 30.1\%; and nondermatophytic, 5.2\% (Table 2). Negative direct exams and positive 
Tabela 1: Distribuição do número de pacientes por idade com aparência anormal das unhas, segundo idade, sexo e presença de onicomicose / Table 1: Distribution of the patients as a whole, patients with abnormal nails and patients with onychomycosis, according to age, sex and percentage.

\begin{tabular}{|c|c|c|c|c|c|c|c|c|c|c|c|}
\hline \multicolumn{4}{|c|}{$\begin{array}{l}\text { Grupo de pessoas } \\
\text { Total sample }\end{array}$} & \multicolumn{4}{|c|}{$\begin{array}{l}\text { Pacientes com unha anormal } \\
\text { Patients with abnormal nails }\end{array}$} & \multicolumn{4}{|c|}{$\begin{array}{l}\text { Pacientes com onicomicose } \\
\text { Patients with onychomycosis }\end{array}$} \\
\hline Idade & Homem & Mulher & Total & Homem & Mulher & Total & $\%$ & Homem & Mulher & Total & $\%$ \\
\hline Age & Male & Female & Total & Male & Female & Total & $\%$ & Male & Female & Total & $\%$ \\
\hline $0-10$ & 102 & 84 & 186 & 6 & 6 & 12 & 6.45 & 1 & 2 & 3 & 1.62 \\
\hline $11-20$ & 132 & 156 & 288 & 19 & 42 & 61 & 21.18 & 5 & 13 & 18 & 6.25 \\
\hline $21-30$ & 173 & 286 & 459 & 41 & 113 & 154 & 33.55 & 21 & 37 & 58 & 12.64 \\
\hline $31-40$ & 260 & 342 & 602 & 84 & 207 & 291 & 48.34 & 44 & 71 & 115 & 19.10 \\
\hline $41-50$ & 184 & 365 & 549 & 71 & 248 & 319 & 58.11 & 43 & 82 & 125 & 22.77 \\
\hline $51-60$ & 130 & 304 & 434 & 62 & 219 & 281 & 64.75 & 38 & 78 & 116 & 26.73 \\
\hline $61-70$ & 84 & 179 & 263 & 47 & 148 & 195 & 74.14 & 26 & 51 & 77 & 29.28 \\
\hline $71-80$ & 39 & 85 & 124 & 25 & 66 & 91 & 73.39 & 13 & 34 & 47 & 37.90 \\
\hline 81 & 3 & 12 & 15 & 3 & 9 & 12 & 80 & 2 & 4 & 6 & 40 \\
\hline $\begin{array}{l}\text { Ignorado* } \\
\text { Not } \\
\text { available* }\end{array}$ & 31 & 34 & 65 & 4 & 2 & 6 & 9.23 & 3 & 2 & 5 & 7.69 \\
\hline Total/Total & 1,138 & 1,847 & 2,985 & 362 & 1,060 & 1,422 & 47.64 & 196 & 374 & 570 & 19.10 \\
\hline $\begin{array}{l}\text { Total válido } \\
\text { Total valid }\end{array}$ & 1,107 & 1,813 & 2,920 & 358 & 1,058 & 1,416 & 48.49 & 193 & 372 & 565 & 19.35 \\
\hline
\end{tabular}

* Para efeito de cálculos esses dados não foram considerados. / These data were excluded from the calculations.

não foram incluídos como onicomicose.

A projeção da prevalência de onicomicose na cidade do Rio de Janeiro tem a estimativa pontual de 19,34\%; se estimada por intervalo, a prevalência situa-se entre $18,61 \%$ e $20,07 \%$, com $95 \%$ de confiança.

A prevalência de onicomicose apresenta histograma simétrico em relação à média de idades. Apenas nos dermatófitos, a proporção de homens com onicomicose nos pés por dermatófito foi maior do que a das mulheres (Tabela 2). A onicomicose nas unhas das mãos estava presente em 96 pacientes $(6,8 \%)$, sendo 30 homens e 68 mulheres, do grupo de 1.416 pacientes com anormalidades ungueais (Tabela 3). Alguns com onicomicose nas mãos tinham lesão concomitante nas unhas dos pés. A relação de onicomicose em pés e mãos foi aproximadamente 5:1 (Tabela 3).

A localização mais frequiente da onicomicose foi no hálux direito. Nos 565 pacientes com onicomicose, a forma clínica subungueal distal da classificação de Roberts foi a mais freqüente. Os dermatófitos mais comumente associados com a onicomicose foram Trichophyton rubrum e $T$. mentagrophytes.

A detecção de fungos não dermatófitos, leveduras não Candida spp. e bactérias foi 5,2\% (Tabela 2), o que chama atenção para esses microorganismos emergentes como causadores de onicomicoses. cultures for Candida were not included as onychomycosis.

The projection of the prevalence of onychomycosis in the city of Rio de Janeiro was estimated at $19.34 \%$; if estimated by interval, the prevalence was between 18.61\% and $20.07 \%$, with $95 \%$ confidence.

The prevalence of onychomycosis presents a symmetrical histogram in relation to the mean ages. Only in the dermatophytes was the proportion of men with onychomycosis in the feet due to dermatophytes greater than that of women (Table 2). Onychomycosis in the fingernails was present in 96 patients (6.8\%), of these 30 were men and 68 were women out of the group of 1,416 patients with ungual abnormalities (Table 3). Some with onychomycosis in the hands had concomitant lesions in their toenails. The ratio of feet to hands in onychomycosis was approximately 5:1 (Table 3).

The most frequent location of onychomycosis was in the right hallux. In the 565 patients with onychomycosis, the most frequent clinical form was distal subungual according to Roberts' classification. The dermatophytes more commonly associated with onychomycosis were Trichophyton rubrum and $\mathrm{T}$. mentagrophytes.

In the detection of nondermatophytic fungi, yeasts other than Candida spp. and bacteria were 5.2\% (Table 2), which calls attention to these emerging microorganisms as etiological agents of onychomycosis. 
Tabela 2: Agentes etiológicos associados com onicomicose de mãos e pés de amostras de 1.416 pacientes com alteração ungueal. / Table 2: Etiological agents associated with onychomycosis of the hands and feet in a sample of 1,416 patients with ungual alterations.

\begin{tabular}{|c|c|c|c|}
\hline \multicolumn{4}{|c|}{ Número de organismos / Number of organisms } \\
\hline Tipo de organismo / Type of organism & Unha do pé / Toenails & Unha da mão / Fingernails & Ignorado / Not available \\
\hline \multirow[t]{3}{*}{ Dermatófito / Dermatófito } & $99(64.7 \%)$ & $4(5.6 \%)$ & 1 \\
\hline & Homem/Male & Homem/Male & \\
\hline & Mulher $/$ Female $=56: 43$ & Mulher/Female $=2: 2$ & \\
\hline Trichophyton rubrum & \multirow{2}{*}{65} & \multirow{2}{*}{2} & \\
\hline Trichophyton rubrum & & & \\
\hline T. mentagrophytes var. mentagrophytes & \multirow{2}{*}{25} & \multirow{2}{*}{1} & \\
\hline T. Maletagrophytes var. Maletagrophytes & & & \\
\hline T. mentagrophytes var. interdigitale & \multirow{2}{*}{5} & \multirow{2}{*}{0} & \\
\hline T. Maletagrophytes var. interdigitale & & & \\
\hline T. tonsurans & \multirow{2}{*}{1} & \multirow{2}{*}{0} & \\
\hline T. tonsurans & & & \\
\hline Microsporum canis & \multirow{2}{*}{0} & \multirow{2}{*}{1} & \\
\hline Microsporum canis & & & \\
\hline Epidermophyton floccosum & \multirow{2}{*}{3} & \multirow{2}{*}{0} & \\
\hline Epidermophyton floccosum & & & \\
\hline \multirow[t]{3}{*}{ Candida spp. / Candida spp. } & $46(30.1 \%)$ & $63(88.8 \%)$ & \\
\hline & Homem/Male & Homem/Male & \\
\hline & Mulher/Female $=9: 37$ & Mulher/Female $=9: 54$ & \\
\hline \multirow{4}{*}{$\begin{array}{l}\text { Não dermatófito e outros microorganismos } \\
\text { Non-dermatophyte and other microorgan- } \\
\text { isms }\end{array}$} & $8(5.2 \%)$ & $4(5.6 \%)$ & \\
\hline & & & \\
\hline & Homem/Male & Homem/Male & \\
\hline & Mulher $/$ Female $=2: 6$ & Mulher $/$ Female $=2: 2$ & \\
\hline Scytalidium dimidiatum & \multirow[t]{2}{*}{4} & \multirow[t]{2}{*}{1} & \\
\hline Scytalidium dimidiatum & & & \\
\hline Curvularia sp. & \multirow[t]{2}{*}{1} & \multirow[t]{2}{*}{0} & \\
\hline Curvularia sp. & & & \\
\hline Trichosporon beigelii & \multirow[t]{2}{*}{3} & \multirow[t]{2}{*}{2} & \\
\hline Trichosporon beigelii & & & \\
\hline Nocardia sp. & \multirow[t]{2}{*}{0} & \multirow[t]{2}{*}{1} & \\
\hline Nocardia $s p$ & & & \\
\hline Total & $153(100 \%)$ & $71(100 \%)$ & \\
\hline
\end{tabular}

\section{DISCUSSÃO}

Nesse estudo, a ocorrência de onicomicose em 2.920 pacientes foi de $19,35 \%$, para a cidade do Rio de Janeiro. A vantagem dessa pesquisa é que todos os pacientes foram examinados pelos dermatologistas, e a confirmação da onicomicose fez-se por meio do exame micológico, não se baseando só no preenchimento de questionário para sua identificação. Foram também considerados a história clínica e fatores de risco, como idade, sexo, atividade físi-

\section{DISCUSSION}

In this study, the occurrence of onychomycosis among 2,920 patients in the city of Rio de Janeiro was $19.35 \%$. The advantage of this research is that all the patients were examined by dermatologists and confirmation of onychomycosis was made through mycological exam and not merely based on the completion of a questionnaire for its identification. Also considered were the clinical history and risk factors, such as age, sex, physical activity, occupa- 
Tabela 3: Número de exames micológicos positivos de 565 amostras de unhas. / Table 3: Number of positive mycological exams out of 565 nail samples.

\begin{tabular}{|c|c|c|c|}
\hline & Unha do pé / Toenails & Unha da mão / Fingernails & Ignorado / Not available \\
\hline NaOH positivo com cultura positiva & 150 & 69 & \\
\hline \multicolumn{4}{|l|}{$\mathrm{NaOH}$ positive with positive culture } \\
\hline & $\begin{array}{c}\text { Homem/Male } \\
\text { Mulher/Female }=67: 86\end{array}$ & $\begin{array}{c}\text { Homem/Male } \\
\text { Mulher/Female }=13: 58\end{array}$ & \\
\hline
\end{tabular}

$\mathrm{NaOH}$ positivo com cultura negativa $\mathrm{NaOH}$ positive with negative culture

\author{
Homem/Male \\ Mulher/Female $=17: 10$
}

1
Total de exames micológicos

Total mycological exams
469

Homem/Male

Mulher/Female $=169: 303$
96

Homem/Male

Mulher $/$ Female $=30: 68$ ca, ocupação e presença de outras doenças facilitadoras (diabetes, doença cardiovascular e psoríase). O estudo baseou-se na chegada aleatória dos pacientes ao consultório dos dermatologistas.

O encontro de onicomicose observada no estudo é diferente da prevalência de 8,4\% $(\mathrm{n}=800), 8,7 \%(\mathrm{n}=$ $1.038), 9,1 \%(\mathrm{n}=2.001)$ e $2.4 \%(\mathrm{n}=1.000)$ relatadas na literatura. ${ }^{2,18-20}$ Definiu-se onicomicose por dermatófito quando, na cultura, um dos fungos desse grupo era isolado. Nessa amostra, a taxa positiva foi de $103 / 2.920=3,53 \%$. A explicação dessa diferença talvez esteja ligada ao uso de medicação, ao clima tropical e à maior tendência ao crescimento de outros microorganismos saprófitas. Estudos em que o dermatologista tinha examinado o paciente e houve confirmação micológica exibiram prevalências altas em relação aos valores de $2,7 \%$ e $2,8 \%$, obtidos usando o método de questionário. ${ }^{16,18}$

O principal parâmetro de associação decorreu do diagnóstico de dermatofitose e da faixa etária correspondente. De fato, a onicomicose esteve presente em apenas $194(12,6 \%)$ de 1.535 pacientes com idade inferior a 40 anos. Na população acima de 40 anos (1.385 pacientes), acima de 50 anos (836 pacientes), acima de 60 anos (402 pacientes) e acima de 70 anos (139 pacientes), a ocorrência de onicomicose foi de 26,73, 29,28, 37,90 e 40,00\%, respectivamente. Os fatores que podem contribuir para o crescimento da prevalência de onicomicose na população mais idosa incluem a taxa reduzida de crescimento da unha e o aumento de trauma em relação ao grupo mais jovem, oferecendo ao organismo maior oportunidade de causar doença no leito ungueal e de invadir a lâmina ungueal.

Detectou-se onicomicose em $17,43 \%$ dos homens e $20,52 \%$ das mulheres que fizeram parte do estudo, sendo significante, no nível de 5\%, a hipótese de que as proporções são diferentes. Assim, as mulheres apresentam maior risco tion and the presence of other facilitative diseases (diabetes, cardiovascular disease and psoriasis). The study was based on the random arrival of patients at dermatological clinics.

The findings on onychomycosis observed in this study differ from the prevalence of $8.4 \%(n=800), 8.7 \%(n=$ $1,038), 9.1 \%(n=2,001)$ and $2.4 \%(n=1,000)$ reported in the literature. ${ }^{2,18-20}$ Onychomycosis has been defined as being caused by a dermatophyte when, in the culture, one of the fungi of that group was isolated. In this sampling, the positive rate was 103/2,920 (3.53\%). The explanation of this difference may be linked to the use of medication, to the tropical climate and the greater tendency for growth of other saprophytic microorganisms. Studies in which the dermatologist had examined the patient and there was a mycological confirmation presented high prevalence in relation to the values of $2.7 \%$ and $2.8 \%$, obtained using the questionnaire method. ${ }^{16,18}$

The main parameter of association arose from the diagnosis of dermatophytosis and corresponding age group. In fact, onychomycosis was present in only 194 (12.6\%) of the 1,535 patients less than 40 years of age. In the population $>40$ years of age (1,385 patients), $>50$ years (836 patients), $>60$ years (402 patients) and $>70$ years (139 patients), the occurrence of onychomycosis was $26.73,29.28,37.90$ and $40.00 \%$, respectively. Factors that can contribute to the increased prevalence of onychomycosis in the more senior population include the reduced rate of nail growth and greater frequency of trauma in relation to the younger age groups. These offer the organism a more propitious opportunity for causing disease in the nail bed and plate.

Onychomycosis was detected in $17.43 \%$ of the men and $20.52 \%$ of the women that were included in the study; this is statistically significant at the 5\% level and proves the hypothesis that the proportions differ. Thus, women are at a greater risk of developing onychomycosis than men. The 
de onicomicose do que os homens. A prevalência no grupo pode ser resultado de maior trauma, tanto por atividades manuais como pelo uso de calçados com salto alto, o que facilita a agressão. A presença de progesterona pode inibir o crescimento dos dermatófitos. Candida spp. foi mais freqüente nas unhas das mãos e em mulheres, e essa observação é mostrada, também, por outros investigadores. ${ }^{21,22} \mathrm{O}$ presente estudo não estabeleceu relação significante entre doenças concomitantes (diabetes, psoríase e doença vascular) e a frequiência de tinea unguium, devido provavelmente ao pequeno número de pessoas com essas doenças.

No estudo de Gupta et al., a prevalência de onicomicose em pacientes com diabetes tipo I foi de $13 \%$. A onicomicose subungueal nas formas distal e lateral foi a mais comum..$^{23}$

A prevalência de onicomicose na unha do pé em pes soas diabéticas em Ontário e Massachusets é estimada em $32,3 \%$ e $34,9 \%$, respectivamente. ${ }^{23}$ Neste trabalho, devido ao pequeno número de pessoas portadoras de diabetes, essa correlação não foi feita.

A relação de pacientes com onicomicose na unha do pé e daqueles com onicomicose nas mãos foi de 5:1. Nos trabalhos de Roberts, de Charif e Elewski e de Gupta, a relação entre onicomicose em pés e mãos foi de $6,1: 1$, de 23:1 e de 10,1:1, respectivamente. Fatores que levam as unhas dos pés a apresentarem alta taxa de onicomicose, comparada à das mãos, são: crescimento lento (unha da mão: 3 - 4mm/ mês vs unha do pé: $1,5-2 \mathrm{~mm} / \mathrm{mês})^{16,25} \mathrm{e}$ maior exposição da unha do pé ao trauma. A unha do hálux foi a mais comprometida, porque é mais predisposta ao trauma. Finalmente, a unha da mão desperta maior atenção do paciente, direcionando busca de médico.

\section{CONCLUSÃO}

Dos 1.416 pacientes com unha anormal clinicamente, a onicomicose foi confirmada em $39,9 \%$. Muitos pacientes com unhas anormais não estavam cientes de que poderiam ter onicomicose nem de que se trata de infecção tratável, sugerindo que há oportunidade de educação do paciente e incremento do conhecimento da onicomicose na população geral quando se indica exame micológico.

A onicomicose não é apenas um problema estético, mas pode exercer efeitos prejudiciais ao indivíduo, acarretar risco particular à saúde do idoso, e as conseqüências de sua disseminação na comunidade podem ser mais dispendiosas do que tratar todos os indivíduos infectados.

\section{AGRADECIMENTO}

Os autores agradecem ao professor Paulo Afonso Lopes pelo estudo estatístico. prevalence of women in the group can be the result of traumas, as much because of manual activities as for the use of high-heeled shoes, which facilitate such injury. The presence of progesterone can inhibit the growth of dermatophytes. Candida spp. was more frequently found in fingernails and in women; this observation has also been reported by other researchers. ${ }^{21,22}$ The present study did not establish a significant relationship between concomitant disease (diabetes, psoriasis and vascular disease) and the frequency of tinea unguium, due probably to the low number of persons in this sample with these diseases.

In the study by Gupta et al., the prevalence of onychomycosis in patients with diabetes type I was $13 \%$. Subungual onychomycosis in distal and lateral forms was the most common. ${ }^{23}$

The prevalence of onychomycosis in the toenails of diabetic patients in Ontario and Massachusets is estimated at $32.3 \%$ and $34.9 \%$, respectively. ${ }^{23}$ In this work, due to the small number of individuals with diabetes, that correlation was not made.

The relationship of patients with onychomycosis in the toenail against those with onychomycosis in the hands was 5:1. In the research done by Roberts, Charif, Elewski and Gupta, this ratio was 6.1:1, 23:1 and 10.1:1, respectively. The factors that explain why the nails of the feet present a higher rate of onychomycosis compared to that of the hands, are as follows: slow growth (fingernail: 3 to $4 \mathrm{~mm} /$ month vs. toenail: 1.5 to $2 \mathrm{~mm} /$ month $)^{16,25}$ and the greater exposure of the toenail to trauma. The nail of the hallux is involved most often, because it is the most liable to trauma. Finally, the patients are much more concerned over their fingernails and hence there is a greater likelihood of seeking medical assistance.

\section{CONCLUSION}

Of the 1,416 patients with clinically abnormal nails, onychomycosis was confirmed in 39.9\%. Many patients with abnormal nails were not aware that they might have onychomycosis nor that it is considered a curable infection. This suggests that there is a need to clarify patients and to provide information regarding onychomycosis for the general population and particularly regarding when a mycological exam is indicated.

Onychomycosis is not only an aesthetic problem, it can cause harmful effects to the individual and health risks, particularly among the elderly. Furthermore, the consequences of its spread throughout a community can be costlier than treating all the infected individuals.

\section{ACKNOWLEDGEMENT}

The authors extend their thanks to Professor Paulo Afonso Lopes for the statistical analysis. 


\section{REFERÊNCIAS / REFERENCES}

1. Kaszuba A, Seneczko F, Lipowczan G et al. Fungal flora in human skin and skin appendages infections in the region of Lódz, Poland. Mycoses 1998 May; 41(5-6): 249-253.

2. Evans EGV. Causative pathogens in onychomycosis and the possibility of treatment resistance: A review. J Am Acad Dermatol 1998 May; 38(5): S32-S56.

3. Gupta AK, Konnikov N, MacDonald P et al. Prevalence and epidemiology of toenail onychomycosis in diabetic subjects: a multicentre survey. Br J dermatol 1998 Oct; 139(4): 665-671.

4. Roberts DT. Prevalence of dermatophyte onychomycosis in the United Kingdom: results of na omnibus survey. Br J Dermatol 1992 Feb; 126 Suppl. 39: 23-7.

5. Jaffe R. Onychomycosis: recognition, diagnosis, and management. Arch Fam Med 1998; 7 (6): 587-92.

6. Vélez A, Linares MJ, Fenández-Roldán JC, Casal M. Study of onychomycosis in Cordoba, Spain: prevailing fungi and pattern of infection. Mycopathologia 1997; 137(1): 1-8.

7. Lubeck DP, Patrick DL, McNulty P et al. Quality of life of persons with onychomycosis. Qual Life Res 1993 Oct; 2 (5): 341-8.

8. Scher RK. Onychomycosis: therapeutic update. J Am Acd Dermatol 1999 Jun; 40 (6 Pt 2): S21 - 6. Review.

9. Boyko WL, Doyle JJ, Seonyoung R, Gause D. Poster presentation, 4th Annual International Meeting of the International Society for Pharmacoeconomics and Outcomes Research, May 23-26, 1999, Arlington, Virginia, USA.

10. Dupuy A, Benchikhi H, Roujeau J-C et al. Risk factors for erysipelas of the leg (cellulits): case - control study. BMJ. 1999 Jun 12; 318 (7198): 1591-4.

11. Levy LA. Epidemiology of onychomycosis in special - risk populations. J Am Podiatr Med Assoc 1997 Dec; 87 (12): 546-50. Review.

12. Evans EGV, Sigurgeirsson B. Double-blind, randomised study of continous terbinafine compored with intermited itraconazole intreatment of toenail onychomicosis. Br Med J 1999, 318: 1031-5. 13. Maraki S, Tselentis Y. Dermatophytoses in Crete, Greece, between 1992 and 1996. Mycoses 1998 Mar; 41(3-4): 175-178.

14. Ninomiya J, Ide M, Ito Y, Takiuchi I. Experimental penetration of Trichophyton mentagrophytes into human stratum corneum. Mycpathologia 1998; 141(3): 153-157.

15. Mezzari A. Frequency of dermatophytes in the metropolitan area of Porto Alegre, RS, Brazil. Rev Inst Med Trop São Paulo 1998 Mar; 40(2): 71-76.

16. Gupta AK, Jain HC, Lynde CW et al. Prevalence and epi- demiology of unsuspected onychomycosis in patient visiting dermatologists' offices in Ontario, Canada - a multicenter of 2001 patients.Int J Dermatol 1997 Oct; 36(10): 783-787.

17. Roberts DT, Evans EGV, Allen R. Fungal nail disease. London, England: Gower Medical Publishing; 1990. p. 86.

18. Heikkila H, Stubb S. The prevalence of onychomycosis in Finland. Br J Dermatol 1995; 133: 699-703.

19. Charif MA, Elewski BE. Prevalence Of onychomycosis in the United States: results of a population based survey. Abstract Form 27. In: International Summit on Cutaneous Antifungal Therapy Programme, May 26-28,1996. Vancourver:1996.

20. Perea S, Ramos MJ, Garau M, Gonzalez A, Noriega AR, del Palacio A. Prevalence and risk factors of tinea unguium and tinea pedis in the general population in spain. J Clin Microbiol. 2000 Sep; 38 (9): 3226-30.

21. Daniel CR. Nonfungal infections. In: Scher RK $<$ Daniel CR, eds. Nails: therapy, Diagnosis, Surgery. Toronto: W. B. Saunders Company, 1990: 120-126.

22. Greer DL. Evolving role of nondermatophytes in onychomycosis. Int J Dermatol 1995; 34: 521-524.

23. Gupta AK, Konnikov N, MacDonald P et al. Prevalence and epidemiology of toenail onychomycosis in diabetic subjects: a multicentre survey. Br J Dermatol 1998; 139: 665-671.

24. Reis CMS, Gaspar PA, Gaspar NK, Santos MG. Avaliação das condições sócio-econômicas na composição da flora dermatofítica do Distrito Federal. An Bras Dermatol 1992, 67 (4): 151-154.

25. Gayoso CW, Mendonça IRSM, Azulay RD. O estudo das unhas. Novos aspectos após o exame de 1.100 pacientes. An Bras Dermatol 1992, 67 (4): 169-181.

26. Montenegro FF, Roselino AMF, Mazzocato TS, Maffei CML. Aspectos clínicos e micológicos de pele sã e lesada em transplantados renais. An Bras Dermatol 1997, 72 (3): 231-6.

ENDEREÇO PARA CORRESPONDÊNCIA: / MAILING ADDRESS:

Jeferson Carvalhaes de Oliveira

Rua Carvalho Alvim N. 201, ap. 101. Tijuca

Rio de Janeiro RJ 20510-100

Tel/Fax: (21) 2569-9777

E-mail:carvalhaes@openlink.com.br 